\author{
Alicja Smaruj \\ Wydział Filologiczny \\ Uniwersytet Gdański \\ e-mail: smarujala@gmail.com \\ ORCID: 0000-0001-6768-971X
}

\title{
Wyobraźnia zorganizowana. Poetyka wiersza kolory Jana Brzękowskiego
}

Spotkanie z twórczością awangardy pierwszej połowy XX wieku wzbogaca czytelnika także dziś - i to w kilku wymiarach. Kształt tej poezji stanowi niepowtarzalne świadectwo ważnego momentu w dziejach sztuki i jest doskonałym pretekstem do zgłębiania początków artystycznej nowoczesności, w szczególny bowiem sposób ogniskują się tutaj rozmaite nurty tego czasu. Swoim charakterem poezja ta odzwierciedla radykalizm i złożoność ówczesnych form wyrazu. Jest tym samym jedynym w swoim rodzaju wyzwaniem, a obcowanie $\mathrm{z}$ nią - treningiem i sprawdzianem poetyckiej wrażliwości.

Interesującą, lecz zapomnianą nieco postacią z kręgu artystów tego czasu jest Jan Brzękowski. Korzystając przede wszystkim z osiągnieć awangardy krakowskiej oraz surrealizmu (nadrealizmu), wytworzył on własną koncepcję poetycką, którą określił mianem metarealizmu. „Metarealizm - w przeciwieństwie do nadrealizmu - opiera się na zorganizowanej wyobraźni" pisał Brzękowski w Wyobraźni wyzwolonej ${ }^{1}$. Rolę dwóch tendencji („wyobraźniowej”, powiązanej z surrealizmem i „konstrukcyjnej”, będącej spuścizną „Zwrotnicy”) w twórczości poety podkreślał Janusz Sławiński:

\footnotetext{
1 Cyt. za: A. Waśkiewicz, Rygory wyobraźni wyzwolonej: o metarealizmie Jana Brzękowskiego, „Pamiętnik Literacki” 1972, z. 3, s. 119-120.
} 
Z jednej strony poezja jako funkcja ruchu wyobraźni, z drugiej - jako działanie poddane idei rygoru. [...] Jego koncepcja mowy poetyckiej miała więc podstawę dramatyczną. Ujmowała poezję jako ustawiczny konflikt między niekonsekwencją przeżycia i konsekwencją wypowiedzi, między swobodą fantazji i dyscypliną jej poetyckich równoważników, między nielogicznością asocjacji i logiką artystycznego obiektu, między czasem aktu wyobraźni i statycznością jego słownych utrwaleń ${ }^{2}$.

Przyglądanie się temu, w jaki sposób utwory Brzękowskiego uobecniają wspomniany konflikt, jak poeta rozwija wyobrażenia i je organizuje, jak to się dzieje, że nie ograniczając rozmachu w budowaniu obrazów, poddaje je jednak pewnej zasadzie, wydaje się możliwe przede wszystkim przez pryzmat poetyki. Proponuję więc taki - nastawiony na poetykę tekstu - typ lektury wiersza kolory z tomu zaciśnięte dookoła ust 3 :

nocą

zgrzaną pośpiechem w tumulcie snów rzęsistym

bez słowa zaciskasz nienawistne palce.

ścigają mnie barwy roztarte $\mathrm{w}$ sitach horyzontu

cynowe deszcze spadają z nieba wzniesionego z rtęci

a zieleń soczysta przechodzi we mnie - pęcznieje jak pęd.

jak Mojżesz z ziemi egipskiej armiami mądrych wężów wśród wód wzniesionych morza z brodą na wiatr rozwianą wymachując laską nóg ciężkim chrzęstem przemierzam żółć chromową piasku i kroczę w czerwieni smagany barwami groźny jak pożar.

bije mnie ciemność i skrzydeł trzepotem uderza po skroni i lęk ogarnia nieznany i słodki

gdy

walcząc $\mathrm{z}$ aniołem w nadchodzącym brzasku

ja, Jakub rozciągnięty na kamieniu nocy

zmartwiałym językiem wołam o pomoc i

krzyczę - gdy znad lasu w drodze do Damaszku jak Pan

na niebie zgrzanym od grzmotów dalekich i woni wstajesz potężny w gromach i blasku i razisz błyskawicą z chromu i potasu ${ }^{4}$.

\footnotetext{
2 J. Sławiński, O poezji Jana Brzękowskiego, „Twórczość” 1961, nr 9, s. 94-95.

3 Warto przypomnieć, że tomik ten został wydany w 1936 roku (a więc w okresie dojrzałości poetyckiej Brzękowskiego, w którym rozwinął on swoją koncepcję metarealizmu) za pośrednictwem grupy „a. r.”, założonej przez Katarzynę Kobro i Władysława Strzemińskiego, który dbał o jego układ graficzny. Znalazły się w nim ilustracje Maxa Ernsta.

4 Tekst wiersza według wydania: J. Brzękowski, zaciśnięte dookoła ust, Warszawa 1936.
} 
W utworze tym, poprzez wykreowanie dynamicznego obrazu poetyckiego, zostało przedstawione bardzo silne i jednocześnie ambiwalentne przeżycie relacji podmiotu mówiącego $\mathrm{z}$ adresatem tekstu, a także doświadczenie swego rodzaju przemiany wewnętrznej. Wiersz oparty jest $\mathrm{w}$ dużej mierze na tej trudnej do jednoznacznej interpretacji sytuacji komunikacyjnej oraz interakcji , ja" lirycznego z surrealistyczną przestrzenią snu. Charakteryzuje się także typowym dla awangardy rozbudowaniem zabiegów semantycznych - ze szczególną, wszechogarniającą niemal obecnością metafory - oraz siłą odniesień intertekstualnych (mam tu na myśli oczywiście motywy biblijne). Kształt tekstu stoi zresztą w zgodzie z językiem poetyckim awangardy krakowskiej: język wiersza przekracza konwencje, słowa wytrącone zostają z neutralności i doprowadzone do oscylacji między wielością możliwych znaczeń; rozbudowany układ syntaktyczny organizuje komunikat liryczny i porządkuje proces wypowiadania przeżyć; także kreowany świat rzeczy, niejako puszczony w ruch, wykracza poza swój naturalny stan; mono$\log$,ja" podporządkowany zaś jest milczącej obecności "ty" lirycznego ${ }^{5}$.

We fragmencie otwierającym utwór, obejmującym dwie całostki składniowe, ukazana zostaje sytuacja podmiotu mówiącego, który jest poddawany działaniom elementów składających się na otaczającą go rzeczywistość. W wyrażeniu "nocą zgrzaną pośpiechem" dochodzi zarówno do personifikacji nocy (charakterystyczne tylko dla ludzi są i zgrzanie się, i pośpiech), jak i metonimicznego przesunięcia znaczenia (zgrzanym można być z powodu pośpiesznego wykonywania czynności, a nie pośpiechem samym w sobie). Następnie pojawia się metafora „w tumulcie snów rzęsistym” - dzięki niej snom nadane zostają właściwości materialne (swoista reifikacja). Proces, jaki tu zachodzi, jest jednak bardziej skomplikowany ${ }^{6}$ : „tumult snów" można by jednocześnie uznać za personifikację, gdyż rzeczownik "tumult" odnosi się do grupy ludzi, jednak wprowadzenie epitetu „[tumult] rzęsisty" sugeruje kierunek odwrotny i nadaje tumultowi cechy zjawiska przyrodniczego (deszczu). Gdyby spróbować rozwinąć tę metaforę porównawczo, można by powiedzieć (decydując się oczywiście na uproszczenie) "sny są jak tłum ludzi, który jest jak rzęsisty deszcz". Istotne wydają się cechy przypisane w ten sposób snom - mają charakter wszechogarniający, otaczają ze wszystkich

\footnotetext{
5 Najsłynniejszym studium języka poetyckiego awangardy krakowskiej jest niewątpliwie praca Janusza Sławińskiego. J. Sławiński, Koncepcja języka poetyckiego awangardy krakowskiej, Wrocław 1965.

6 Zachodzi tu zjawisko (widoczne także później), które Jerzy Pelc określił mianem „oscylacji semantycznej metafory". Omówione zostało w: J. Sławiński, Koncepcja języka poetyckiego awangardy krakowskiej, s. 50.
} 
stron, odczuwane są jak najbardziej realnie, zmysłowo, jako coś materialnego. (Ważny jest także wskazany przez „rzęsistość” deszcz, gdyż metaforyka pogodowa wraca $\mathrm{w}$ wierszu kilkakrotnie). $\mathrm{W}$ następnym wersie osoba mówiąca zwraca się bezpośrednio do adresata utworu: „bez słowa zaciskasz nienawistne palce". Na uwagę zasługuje epitet "nienawistne palce”, ponieważ można odczytać go na dwa sposoby: palce są znienawidzone lub (choć uznając tę dwuznaczność za celową ekwiwokację, należałoby raczej napisać „oraz") nienawidzące. W obu przypadkach „palce” stanowią synekdochę ich milczącego właściciela, zmienia się zaś podmiot odczuwający nienawiść w jednym przypadku jest nim nadawca, a w drugim odbiorca komunikatu, dzięki czemu zbudowane zostaje szczególne napięcie między tymi osobami.

W kolejnych trzech wersach utworu pojawiają się odpowiednio trzy elementy przestrzeni (rzeczywistości onirycznej), w której znajduje się i której bardzo silnie doznaje "ja" mówiące. W sformułowaniu wprowadzającym pierwszy z nich („ścigają mnie barwy") kolory są zanimizowane, co powoduje dynamizację obrazu poetyckiego i aktywizuje rzeczywistość (podmiot zdaje się jej podlegać). Dalej „barwy” określone są metaforycznie jako „roztarte w sitach horyzontu", a więc takie, które uległy pewnemu przekształceniu - rozdrobnieniu, redukcji. Wywołuje to też skojarzenie z plastyką malarz przed rozpoczęciem pracy rozciera pigment. Widoczne są $\mathrm{w}$ tym fragmencie zabiegi podobne do wcześniejszych: abstrakcyjne barwy (równolegle do wcześniejszego ożywienia) z jednej strony ulegają reifikacji i stają się materialnym tworzywem, „rozcieralną" substancją, z drugiej jednak sensualizm jest zaburzony przez to, jak je roztarto (,W sitach horyzontu" w czymś niedotykalnym). Kolejnym elementem są "cynowe deszcze" (epitet sugeruje zmianę postrzegania właściwości deszczu, okazuje się on czymś o ciężarze i kolorze metalu) „spadające z nieba wzniesionego z rtęci”. Na omówienie zasługuje imiesłów „wzniesione”, ponieważ nie tylko sygnalizuje, iż niebo znajduje się wysoko, ale też, że aby się tam pojawić, zostało poddane jakiemuś działaniu. Ponadto niebo z abstrakcyjnego staje się materialne, gdyż jest „z rtęci”. Trzeci element to „zieleń soczysta” (za pomocą synestezji wrażenie wzrokowe wzbogacone zostaje o doznania właściwe innym zmysłom). Działanie zieleni daje się interpretować (znów) dwojako „przechodzi we mnie”, czyli przemieszcza się po moim wnętrzu (ożywienie) lub przeistacza się we mnie. Dalej zieleń „pęcznieje jak pęd”. Porównanie to jest figurą pseudoetymologiczną, jednocześnie „pęd” daje się (ponownie!) odczytywać podwójnie - jest to przecież homonim i znaczy zarówno część rośliny (ścisłe powiązanie z zielenią i bliskimi „pęcznieniu” pączkami), jak też stan szybkiego przemieszczania się (korespondujący dobrze $z$ dynamizmem obecnym w utworze). 
Drugą dającą się wyraźnie wydzielić częścią wiersza jest cała kolejna strofoida, na którą składa się rozbudowane, niemal homeryckie porównanie. Wyróżnia ją to, że - inaczej niż w rozpoczęciu oraz zakończeniu utworu - podmiot mówiący został w niej wykreowany jako wykazujący się zdecydowaniem wykonawca czynności (czasowniki „przemierzam” i „kroczę”), którego cechuje siła („groźny jak pożar"), a nawet pewien majestat (przytoczone wyżej czasowniki, nawiązania biblijne). Już sam trzon porównania (,jak Mojżesz [...] przemierzam [...] i kroczę") uruchamia bogactwo znaczeń wynikających z pojawienia się biblijnej postaci, zdanie zostaje jednak uzupełnione o wyliczenie, którego człony przywołują (w części zwielokrotnione i zdynamizowane) obrazy z Księgi Wyjścia („z ziemi egipskiej”, „armiami mądrych wężów”, „,wśród wód wzniesionych morza”, „z brodą rozwianą na wiatr", „wymachując laską"). Warto zwrócić uwagę na konstrukcję niektórych z nich: „armiami wężów [...] przemierzam” jest zdaniem dopuszczalnym składniowo $w$ języku ogólnym tylko przy zignorowaniu relacji semantycznych między członami i daje się zakwalifikować jako hypellage; „wśród wód wzniesionych" to dynamizująca fragment aliteracja; "broda rozwiana na wiatr" stanowi kontaminację utartych związków wyrazowych "rozwiane włosy” (tu broda) i „rzucać słowa na wiatr”. Przywołane czynności zostają także uzupełnione o metonimie bliskie sensualizmowi początkowej części utworu: „nóg ciężkim chrzęstem przemierzam żółć chromową piasku” (warta odnotowania jest też instrumentacja głoskowa, wprowadzona przez powtórzenia [̌̌] i [š]). Najważniejsze jednak jest to, iż aktywności te dzieją się w obrębie kolorów (co zdaje się ze względu na tytuł czymś więcej niż metonimią, kolory zyskują wartość symboliczną): „przemierzam żółć” i „kroczę w czerwieni", a podmiot mówiący, choć pełen siły (porównanie "groźny jak pożar"), nadal wydaje się zmagać z rzeczywistością, w której się przemieszcza, jest „smagany barwami” (raz jeszcze abstrakt podlega reifikacji do czegoś dotykalnego).

W trzeciej części osoba mówiąca traci swoją siłę (być może miała ją tylko pozornie): „bije mnie ciemność i skrzydeł trzepotem uderza po skroni”. "Ciemność" ulega zarówno personifikacji (bić może tylko człowiek; warto dodać, że choć personifikacji w utworze jest kilka, wykorzystują one nie najbardziej ludzkie przymioty człowieka), jak i animizacji; pojawia się również metonimia (uderzanie "trzepotem" zamiast samymi skrzydłami) oraz synekdocha („po skroni” zamiast po skroniach lub po twarzy). Następnie podmiot liryczny „lęk ogarnia nieznany i słodki". To oksymoroniczne stwierdzenie pozwala domyślać się wielowarstwowości sensów utworu. Pojawienie się kolejnych obrazów poetyckich poprzedzone jest wyodrębnionym graficznie spójnikiem "gdy". Uwypukla on osadzenie "akcji" wiersza w czasie, a także 
powoduje jedyne tak wyraźne zawieszenie intonacyjne - jest zapowiedzią zmiany i zbliżania się punktu kulminacyjnego. W obrazach następujących po nim rzeczywiście dokonuje się przemiana:

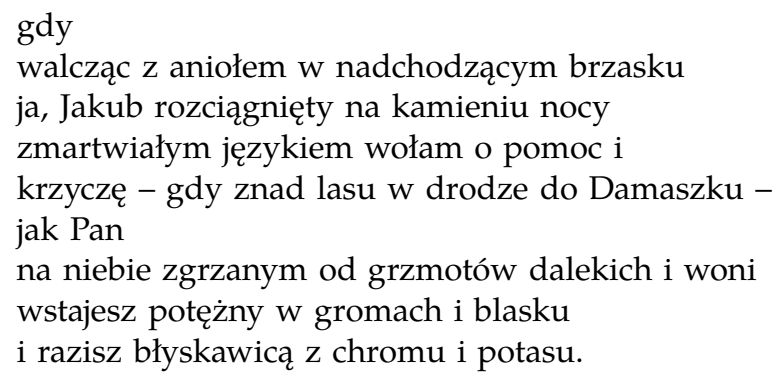

Wprowadzone zostają dwie kolejne postaci biblijne, w przełomowych dla siebie momentach doznawania ogromu mocy Boga - Jakub walczący z aniołem (aliteracyjne ,ja, Jakub" ukazuje siłę utożsamienia się "ja" lirycznego z tym, który w historii biblijnej zaraz miał zostać nazwany Izraelem) i Szaweł $\mathrm{w}$ chwili spotkania Chrystusa (więc również na niedługi czas przed zmianą imienia) oraz, co wydaje się przynajmniej równie istotne, powraca adresat wiersza. Zostaje on w rozbudowany sposób porównany do gromowładnego Boga, „wstaje”, , jak Pan / na niebie zgrzanym od grzmotów dalekich i woni”. „Niebo” jest tutaj (podobnie jak na początku utworu „noc”) uosobione i "zgrzane", przyczyną zgrzania okazują się jednak tym razem "grzmoty dalekie i wonie" (zaktywizowane w ten sposób zostają zmysły słuchu i węchu czytelnika, powraca także występująca na początku metaforyka meteorologiczna). Czynności, które wykonuje adresat tekstu wobec podmiotu mówiącego i ich określenia świadczą o jego sprawczej sile. „Wstaje potężny w gromach i blasku / i razi błyskawicą z chromu i potasu” - należy odnotować ponowne pojawienie się nazw metali i wprowadzenie tym samym zmiany właściwości błyskawicy, podobnie jak wcześniej deszczu. Działania te, wraz z "lękiem nieznanym i słodkim” oraz kontekstem biblijnym, uruchamiają skojarzenia związane $\mathrm{z}$ jednej strony ze świadectwami ekstatycznego doświadczenia obecności Boga (np. wobec św. Teresy), z drugiej destrukcyjnej potęgi Gromowładnego. Warto podkreślić, że w następującym po spójniku "gdy" fragmencie wciąż trwa zmaganie podmiotu, jednak teraz nie tylko jest on bity (jak wcześniej przez ciemność), ale podejmuje walkę. Przeciwnikiem okazują się już nie bezosobowe barwy i ciemność, ale anioł i „ty” liryczne, rzecz dzieje się zaś w napełniającym nadzieją „nadchodzącym brzasku". Dochodzi także do samookreślenia się „,ja” poprzez wypowiedzenie wprost zaimka osobowego. 
Warto wrócić jeszcze do najważniejszych płaszczyzn symbolicznych występujących w utworze: metali, pogody oraz kolorów. Pełnią one w wierszu, obok opisanych powyżej zabiegów metaforycznych, istotną funkcję. Metale („cyna”, „rtęć", ,"chrom”, ,potas") zdają się odgrywać przynajmniej potrójną rolę. Po pierwsze, są znakiem przemysłowej nowoczesności i innowacyjności (które to wartości pozostały istotne dla poety wywodzącego się ze zwrotniczan). Po drugie, przyczyniają się do odrealniania przestrzeni, w której przebywa podmiot mówiący - to odrealnienie i niepokojące, i postępujące bardzo konsekwentnie. Po trzecie, potęgują wrażenie osaczenia podmiotu mówiącego - to pierwiastki w znacznej większości trujące dla człowieka. Zbliżoną funkcję zdają się mieć zjawiska pogodowe (z którymi metale w wierszu ściśle się łączą): ogarniają podmiot mówiący, są znakiem atakującej go przestrzeni i sygnałem przełomowego momentu (zwłaszcza końcowe grzmoty i błyskawica).

Wreszcie omówić należy także tytułowe kolory (w wierszu nazywane „,barwami”, które „ścigają" i „smagają”, przez co tym bardziej uzasadnione jest wymienienie ich obok metali i deszczów czy burzy): „Zieleń", „żółć” i ",czerwieńn". Kolory te, podane w formach rzeczownikowych, prowokują do odczytań symbolicznych 7 . Zieleń jest znakiem życia, przyrody, nadziei, młodości i niedojrzałości. Takie jej rozumienie, dość konwencjonalne, usprawiedliwić można przez kontekst, w jakim pojawia się w utworze: jest pierwszą barwą (początek) i „pęcznieje jak pęd” (natura). Żółć oznacza wieczność, stałość, jasność, świt, natchnienie, urodzaj, wiedzę i pojawia się w tekście w momencie uniesienia podmiotu mówiącego, który ją ,jjak Mojżesz [...] przemierza żółć [...] piasku". Czerwień wreszcie to symbol ciała ludzkiego, energii, gniewu, miłości, potęgi, błyskawicy oraz rewolucji (czy szerzej stronnictw lewicowych). Konsekwentnie, tak jak w przypadku poprzednich kolorów, jej obecność zostaje „poszerzona” przez umieszczenie w tekście elementów kojarzonych z czerwienią - Morza Czerwonego i pożaru. Ostatnie $\mathrm{z}$ wymienionych znaczeń czerwieni daje się umotywować biografią Brzękowskiego (związany był, jak cała zresztą awangarda krakowska, ze środowiskiem lewicowym) oraz innymi tekstami z tomiku (zwłaszcza poematem Leforest). Nie tylko dobór barw, ale też ich kolejność zdaje się nieprzypadkowa. Przechodzą od chłodnej do najcieplejszej, od tej towarzyszącej łodyżce i pąkowi, przez tę częstą u kwiatów, do charakterystycznej dla dojrzałego owocu. Można je więc traktować jako próbę odzwierciedlenia rozwoju podmiotu mówiącego, jego relacji z odbiorcą i samego tekstu. Doprowadzają

7 Znaczenia zgodnie z: W. Kopaliński, Stownik symboli, Warszawa 1990. 
„ja" liryczne na próg kulminacji i oddają nieznanemu: na początku trzeciej części zamiast smagających barw jest „ciemność”, w której nie widać już kolorów.

Wiersz Brzękowskiego zdaje się wypowiedzią na temat niezwykłego doświadczenia psychologicznego (czy wręcz duchowego?) podmiotu mówiącego. W przenikających się na zasadzie onirycznego asocjacjonizmu obrazach "ja" podlega przemianom, zmaga się z przestrzenią i drugą osobą (być może są one jedynie wytworami wyobraźni śniącego podmiotu), aby na końcu wreszcie, po kryzysie ciemności, „w nadchodzącym brzasku” doznać przełomu. Destrukcji i odrodzenia.

\title{
Bibliografia
}

Brzękowski Jan (1936), zaciśnięte dookoła ust, Warszawa: Sgł. gł. Dom Książki Polskiej. Brzękowski Jan (1958), Awangarda, „Przegląd Humanistyczny”, nr 1, s. 46-81.

Brzękowski Jan (1980), Wiersze wybrane, Warszawa: Czytelnik.

Janicka Krystyna (1985), Surrealizm, Warszawa: Wydawnictwo Artystyczne i Filmowe. Kopaliński Władysław (1990), Słownik symboli, Warszawa: Wydawnictwo „Wiedza Powszechna".

Plauszewski Andrzej (1966), Realizacja teoretycznych postulatów awangardy krakowskiej w poezji Jana Brzękowskiego, Łódź: Łódzkie Towarzystwo Naukowe.

Przyboś Julian (1959), O metaforze, „Twórczość", nr 3, s. 105-116.

Sławiński Janusz (1961), O poezji Jana Brzękowskiego, „Twórczość”, nr 9, s. 82-101.

Sławiński Janusz (1965), Koncepcja języka poetyckiego awangardy krakowskiej, Wrocław: Zakład Narodowy im. Ossolińskich.

Waśkiewicz Andrzej (1972), Rygory wyobraźni wyzwolonej: o metarealizmie Jana Brzękowskiego, „Pamiętnik Literacki”, nr 3, s. 111-141.

\section{Imagination Organized: The Poetics of Jan Brzękowski's Poem Kolory}

\begin{abstract}
The article interprets Jan Brzękowski's poem kolory [couleurs]. Accepting the assumption that the reading of the Cracow avant-garde poetry, including Brzękowski's works, requires the textual approach, the author of the article gives an in-depth discussion of rhetorical figures (especially metaphors) and symbolic motifs (metals, colours, weather phenomena). Such reading of kolory turns the poem into a statement about the unique psychological (or even spiritual) experience of the lyrical self, who, after a crisis of darkness, has an insight "in the breaking dawn".
\end{abstract}

Keywords: lyric poetry, poetic avant-garde, poetic imagination, poetics, metaphor 